\title{
RUPTURA COM O LUGAR E DESTRUIÇÃO DE IMAGENS ESPACIAIS EM CIDADES REASSENTADAS: O CASO DE ITACURUBA-PE
}

\author{
RUPTURA COM EL LUGAR Y DESTRUCCIÓN DE IMÁGENES ESPACIALES EN CIUDADES \\ REUBICADAS: EL CASO DE ITACURUBA, BRASIL
}

\section{DISRUPTION WITH PLACE AND DESTRUCTION OF SPATIAL IMAGES IN RESETTLED CITIES: THE CASE OF ITACURUBA, BRAZIL}

\section{MOREIRA, FERNANDO DINIZ}

Arquiteto, Ph.D em Arquitetura, University of Pennsylvania, Professor Associado do Departamento de Arquitetura e Urbanismo da Universidade Federal de Pernambuco (UFPE), e-mail: fernando.diniz.moreira@gmail.com

\section{MAIA, RAFAELA TETI TIBURCIO}

Arquiteta e Urbanista pela Universidade Federal de Pernambuco (UFPE), e-mail: rafaelateti@gmail.com

\section{RESUMO}

Este artigo busca contribuir para uma discussão sobre as possiveis consequências de um rompimento do vínculo com o lugar a partir do estudo do reassentamento de uma cidade, Itacuruba-PE, que existia à beira do Rio São Francisco devido à construção da Usina Hidrelétrica de Itaparica. Itacuruba passou a ser uma das cidades brasileiras que mais se utiliza de antidepressivos em termos percentuais, atingindo o equivalente a $63 \%$ da população com depressão, segundo dados do Conselho Regional de Medicina de Pernambuco (CREMEPE). 0 artigo objetiva identificar os elementos espaciais que faziam parte da construção da identidade do morador da antiga Itacuruba e expor as rupturas provocadas, que podem ter tido como consequência os impactos à saúde mental. Para tal, foi feito um aprofundamento teórico sobre os temas de rompimento dos vínculos do grupo com o lugar no qual estava enraizado, buscando-se apoio nos estudos de Mircea Eliade, sobre a atribuição de um caráter sacro por sociedades tradicionais aos lugares onde vivem, e nos de Maurice Halbwachs, sobre memória coletiva e as imagens espaciais que a sustentam. Buscou-se explicar o contexto do nacional-desenvolvimentismo, a construção da hidrelétrica e as particularidades do processo por meio de pesquisa documental nos arquivos da CHESF. Para revelar os impactos provocados pelo plano da nova cidade, foram aplicados estudos da morfologia urbana (Panerai, Lynch e Cullen) sobre as formas da velha e nova cidade de Itacuruba, além de visita de campo e aplicação de entrevistas a 15 moradores que vivenciaram o reassentamento.

PALAVRAS-CHAVE: reassentamento de cidade; urbanismo moderno; memória coletiva; morfologia urbana; dessacralização.

\section{RESUMEN}

Este artículo busca contribuir a una discusión sobre las posibles consecuencias de una ruptura en el vínculo con el lugar desde el estudio de la reubicación de una ciudad, Itacuruba-PE, que existía en las orillas del río São Francisco debido a la construcción de la Planta Hidroeléctrica de ltaparica. Itacuruba se tornó uma de las ciudades brasileñas que más se utiliza de antidepresivos en términos porcentuales, alcanzando porcentaje del $63 \%$ de la población con depresión, según datos del Consejo Regional de Medicina de Pernambuco (CREMEPE). El artículo tiene como objetivo identificar los elementos espaciales que formaron parte de la construcción de la identidad del habitante de la antigua Itacuruba y exponer las rupturas causadas, que pueden haber tenido un impacto en la salud mental. Con este fin, se realizó un estudio teórico sobre los temas de desconexión de los lazos del grupo con el lugar con el que se arraigó, buscando apoyo en los estudios de Mircea Eliade, sobre la atribución de un carácter sagrado por las sociedades tradicionales a los lugares donde viven, y Maurice Halbwachs, sobre la memoria colectiva y las imágenes espaciales que la respaldan. Intentamos explicar el contexto del desarrollismo nacional, la construcción de la planta hidroeléctrica y las particularidades del proceso a través de la investigación documental en los archivos de la CHESF. Para revelar los impactos causados por el nuevo plan de la ciudad, se aplicaron estudios de morfología urbana (Panerai, Lynch y Cullen) en las formas de la ciudad antigua y nueva de Itacuruba, además de una visita de campo y la aplicación de entrevistas a 15 residentes que vivenciaron la reubicación.

PALABRAS CLAVES: reubicación de la ciudad; urbanismo moderno; memoria colectiva; morfología urbana; profanación.

\section{ABSTRACT}

This article seeks to contribute to a discussion on the possible consequences of a break in the link with the place from the study of the relocation of a city, Itacuruba$P E$, Brazil, which existed on the banks of the São Francisco River due to the construction of the Itaparica Hydroelectric Plant. Itacuruba is the one of Brazilian cities that used the most antidepressants in percentage terms, reaching the equivalent of $63 \%$ of the population with depression, according to data from the Regional Council of Medicine of Pernambuco (CREMEPE). The article aims to identify the spatial elements that were part of the construction of the identity of the inhabitant of the old Itacuruba and to expose the ruptures caused, which may have had the impact on mental health. To this end, a theoretical study was done on the themes, breaking the 
group's ties with the place with which it was rooted, seeking support in the studies of Mircea Eliade, on the attribution of a sacred character by traditional societies to the places where they live, and Maurice Halbwachs, on collective memory and the spatial images that support it. We sought to explain the context of national developmentalism, the construction of the hydroelectric plant, and the particularities of the process, through documentary research in the CHESF archives. To reveal the impacts caused by the new city plan, studies of urban morphology (Panerai, Lynch and Cullen) on the forms of the old and new city of Itacuruba were applied, in addition to field visits and interviews with 15 residents who experienced the resettlement.

KEYWORDS: Reseltled city; modern urbanism; collective memory; urban morphology; desecration.

Recebido em: $17 / 02 / 2020$

Aceito em: $14 / 05 / 2020$

\section{INTRODUÇÃO}

Nas últimas décadas do século XX, muitas cidades foram planejadas e construídas no Brasil, em sua maioria influenciadas pelos ditames do urbanismo moderno, para reassentar comunidades removidas por hidrelétricas. A porção do sertão nordestino banhado pelo rio São Francisco, entre os estados de Pernambuco, Alagoas e Bahia recebeu grandes usinas hidrelétricas como Paulo Afonso, Xingó e Itaparica. A construção desta última causou a submersão de $27,21 \%$ do território do município de Itacuruba-PE e envolveu o reassentamento de sua sede, que era localizada na região ribeirinha (CHESF, 1986).

Elaborado pela Secretaria de Habitação de Pernambuco (SEHAB) - com o suporte da Companhia Hidroelétrica do São Francisco (CHESF) - o projeto de reassentamento, finalizado em 1988, promoveu a ruptura de relações sociais, práticas culturais, costumes e atividades de subsistência que estavam atrelados ao rio São Francisco. A população, que possuía uma forte relação com o rio, foi deslocada para longe deste, em uma nova cidade, inspirada no urbanismo moderno e muito diferente da antiga em termos morfológicos.

Alguns anos após esse processo de reassentamento, passaram a ser identificadas graves patologias no campo da saúde mental desta população. Em 2007, segundo o Conselho Regional de Medicina de Pernambuco (CREMEPE), Itacuruba atingiu um percentual de $63 \%$ da população com depressão ${ }^{1}$. Além disso, a dependência de psicotrópicos fez Itacuruba ficar conhecida como "a cidade dos depressivos", chegando a ser detentora do maior índice de suicídios do país, com valores bem acima da média mundial².

Os impactos à saúde mental podem estar relacionados ao rompimento dos vínculos do grupo com o lugar com o qual estava enraizado. A perda do lugar de um grupo é um momento traumático e cria uma situação de incerteza, pois as tradições, hábitos e cultura que o grupo estabelecia com o lugar não mais existem. Maurice Halbwachs ([1950]1990) trata essa relação por meio da memória coletiva. Para ele, o entorno material recebe influências do grupo ao mesmo tempo que o influencia, conformando imagens espaciais sob as quais as memórias coletivas se apoiam. Mircea Eliade ([1957]1992), por sua vez, mostrou que sociedades tradicionais atribuem um caráter sacro aos lugares onde vivem, consagrando-os por meio de diversas simbologias ${ }^{3}$. A quebra desse vínculo remete, portanto, a uma situação de catástrofe, na qual a comunidade retorna ao espaço desconhecido, amorfo, caótico.

Este artigo busca identificar os elementos espaciais que faziam parte da construção da identidade do morador da velha ${ }^{4}$ Itacuruba e expor as rupturas provocadas, que podem ter tido como consequência os impactos à saúde mental acima elencados. Pretende-se, assim, contribuir para uma discussão sobre as possíveis consequências de um rompimento do vínculo com o lugar. Para tal, buscou-se apoio sobre os temas da dessacralização (Eliade) e da destruição das imagens espaciais, que sustentam a memória coletiva (Halbwachs), assim como as possíveis consequências de suas rupturas. Logo após essas publicações, aparecem no campo do urbanismo uma série de estudos que apontaram uma análise mais aprofundada da morfologia urbana associada à percepção dos cidadãos por meio de autores como Kevin Lynch, Gordon Cullen e Phillippe Panerai, também explorados neste artigo. Além disso, buscou-se entender o contexto do nacional-desenvolvimentismo e da estratégia de construção de hidrelétricas, assim como explicar as particularidades do processo, por meio de pesquisa documental nos arquivos da CHESF. Para revelar os impactos provocados pelo plano urbanístico, foram aplicados estudos da morfologia urbana sobre as formas da velha e nova cidade de Itacuruba, buscando identificar as semelhanças e diferenças que podem ter contribuído para esta sensação de perda de vínculo, além de visita de campo e aplicação de entrevistas a 15 moradores que experimentaram a transferência da velha para a nova cidade.

$\mathrm{O}$ artigo está estruturado em cinco partes. A primeira discute os conceitos teóricos de memória coletiva e dessacralização, acompanhada pela apresentação das ferramentas de análise urbana de Philippe Panerai (2006), Kevin Lynch ([1960]1982) e Gordon Cullen ([1961]1983). A segunda parte trata de uma contextualização do objeto de estudo, desde o contexto do nacional-desenvolvimentismo (1930-1970), a importância do rio São Francisco, a construção da Usina de Itaparica e a proposta de reassentamento. A 
terceira e quarta partes correspondem a uma apresentação e análise da velha e da nova cidade de Itacuruba, respectivamente, à luz dos princípios de análise urbana. Por fim, a quinta parte apresenta uma análise comparativa das duas cidades apontando as semelhanças e diferenças, associadas às atribuições simbólicas identificadas no discurso dos moradores.

\section{BREVE PANORAMA TEÓRICO}

\section{Os lugares de memória na construção da identidade}

Na década de 1950, Maurice Halbwachs (1990), em Memória Coletiva, já apontava a importância de se entender a memória enquanto fenômeno coletivo e social. Em outras palavras, a memória corresponde a um fenômeno de construção coletiva, sujeito a oscilações e mudanças constantes. Para Hallbwachs, um dos aspectos essenciais da memória coletiva é o constante contato do grupo com o seu entorno material, que possui marcas de diferentes tempos. É por meio da relação do grupo com os objetos circundantes que se configuram o que Halbwachs chama de imagens espaciais: "[...] todas as ações do grupo podem se traduzir em termos espaciais, e o lugar ocupado por ele é somente a reunião de todos os termos. Cada aspecto, cada detalhe desse lugar em si mesmo tem um sentido que é inteligível apenas aos membros do grupo [...]". (HALBWACHS, 1990, p.133). Alinhado às suas ideias, Pierre Nora também reforça essa relação ao evidenciar que "[...] a memória se enraíza no concreto, no espaço, no gesto, na imagem, no objeto" (1993, p. 9).

Para Michael Pollak, a memória é sobretudo uma "operação coletiva dos acontecimentos e das interpretações do passado que se quer salvaguardar" $(1989$, p. 7), possuindo duas funções essenciais: manter a coesão interna e defender as fronteiras daquilo que um grupo tem em comum, na qual se inclui o território. Assim, segundo ele, a memória é sobretudo uma construção coletiva cuja função é "fornecer um quadro de referências" (POLLAK, 1989, p. 7). Pollak ainda aponta que a memória tem como elementos constitutivos acontecimentos, personagens e lugares. Em relação aos dois primeiros, trata-se das experiências vividas pessoalmente; seguidas por aquelas que não foram vivenciadas diretamente pelo sujeito, mas pelo grupo ou coletividade a qual pertence. Já os lugares correspondem aos lugares de memória, ou seja, lugares particularmente atrelados às lembranças, podendo ser um local de férias de infância ou até mesmo monumentos e espaços da cidade. O conceito de lugares de memória também foi abordado por Nora (1993), que buscou estabelecer laços de continuidade entre passado e presente, dotando-o de três instâncias: material, funcional e simbólica, as quais devem sempre coexistir.

A partir do exposto, podemos inferir que as imagens espaciais são os elementos estruturadores dos lugares de memória. São reflexo da relação do grupo com o seu entorno material e apresentam papel fundamental na memória coletiva: elas conformam um quadro espacial que serve de referência para o grupo a qual pertencem.

Não há memória coletiva que não se desenvolva num quadro espacial. Não seria possível compreender que pudéssemos recuperar o passado, se ele não se conservasse, com efeito, no meio material que nos cerca. É sobre o espaço, sobre o nosso espaço - aquele que ocupamos, por onde sempre passamos, ao qual sempre temos acesso, e que em todo caso, nossa imaginação e nosso pensamento são capazes de reconstruir. Não há, com efeito, grupo nem gênero de atividade coletiva, que não tenha qualquer relação com o lugar. (HALBWACHS,1990, p. 143).

Pollak ainda trata da relação entre memória coletiva e identidade. Segundo ele, a memória é um "elemento constituinte do sentimento de identidade" $(1992$, p.5) e a pontua como um fator de extrema importância para o sentimento de continuidade e coerência para a reconstrução de um grupo em si. Dessa forma, é possível concluir que, ao habitar, as imagens espaciais conformam um quadro espacial que estrutura a memória coletiva enquanto lugares de memória. A memória coletiva, por sua vez, é parte integrante do sentimento de identidade. Logo, os lugares de memória não seriam, senão, parte constituinte da identidade de um grupo.

\section{Da construção de vínculos às rupturas identitárias}

Se os vínculos identitários estão atrelados à dimensão espacial que o configura, a perda dessa dimensão espacial corresponde a uma ruptura com esses vínculos. Em O Sagrado e o Profano, Mircea Eliade compreende essa relação por meio do comportamento religioso de consagração do lugar. Para ele, o sagrado e o profano representam duas formas de ser no mundo, na qual a primeira se opõe à segunda ao se manifestar por meio de hierofania, ou seja, "o ato de manifestação do sagrado" (ELIADE, 1992, p. 13):

Para o homem religioso, o espaço não é homogêneo: o espaço apresenta roturas, quebras; há porções de espaço qualitativamente diferentes das outras. [...] Há, portanto, um espaço 
sagrado, e por consequência "forte", significativo, e há outros espaços não sagrados, [...] sem estrutura nem consistência, em suma, amorfos. (ELIADE, 1992, p. 17).

O mundo passa a existir, portanto, a partir do estabelecimento dessa rotura. É a experiência religiosa que permite fundar o mundo e atribuir valor existencial a ele: "Para viver no mundo é preciso fundá-lo - e nenhum mundo pode nascer no 'caos' da homogeneidade e do espaço profano" (ELIADE, 1992, p.17). Para fundar o mundo é preciso primeiramente reconhecer o terreno sagrado, que estabelece a existência de um ponto fixo, compreendido enquanto centro, que orientará o grupo. A perda desse vínculo passa a representar um retorno ao caos, ao desconhecido. Como exemplo, ele cita a história de uma tribo nômade australiana que tinha um poste como eixo cósmico. Ao ser fincado, ele sacralizava a terra da tribo. Este poste era transportado pela tribo durante as peregrinações e guiava a sua direção conforme a sua inclinação. Quando ele se quebrou "toda a tribo foi tomada de angústia; seus membros vaguearam durante algum tempo e finalmente sentaramse no chão e deixaram-se morrer" (ELIADE, 1992, p. 23).

A hierofania assemelha-se à construção das imagens espaciais defendidas por Halbwachs. Este último admite que a memória coletiva está apoiada em um estado de equilíbrio mental que depende da permanência das imagens espaciais. O contato diário com o lugar e as coisas conferem "uma imagem de permanência e estabilidade" (1990, p. 131):

[...] É certo que mais de uma perturbação psíquica seja acompanhada por uma espécie de ruptura do contato entre nosso pensamento e as coisas, de uma incapacidade de reconhecer os objetos familiares, de tal modo que nos encontramos perdidos em um meio estranho... Até mesmo fora dos casos patológicos, quando algum acontecimento nos obriga também a nos transportarmos para um novo entorno material, antes de a ele nos adaptarmos, atravessamos um período de incerteza, como se houvéssemos deixado para trás toda a nossa personalidade, tanto é verdade que as imagens habituais do mundo exterior são inseparáveis do nosso eu. (HALBWACHS,1990, p. 131).

A importância da imagem para o equilíbrio de um grupo também é abordada por Kevin Lynch em $A$ Imagem da Cidade (1982), quando afirma que "a imagem de um bom ambiente dá, a quem a possui, um sentido importante de segurança emocional" (1982, p. 14-15). Segundo Halbwachs, a perda do lugar de um grupo rompe a relação estabelecida entre pensamentos e objetos, inserindo o grupo em uma situação de incerteza, na qual a tradição que o ampara - e que representa sua única razão de ser - não mais existe.

Deduzimos, portanto, que a perda dos vínculos identitários estabelecidos entre grupo e espaço impacta diretamente na saúde mental do grupo. Dentre as consequências apresentadas tem-se a perda do sentido existencial que, segundo Eliade (1992), é ocasionado por um retorno ao caos e para Halbwachs (1990) é fruto da perda das imagens espaciais, apontando para uma sensação de desorientação e falta de ponto de apoio.

\section{DESENHO METODOLÓGICO}

\section{Ferramentas de análise: morfologia urbana}

Entre o final dos anos de 1950 e a década de 1960, muitas realizações do urbanismo moderno foram alvo de duras críticas por autores das mais diversas perspectivas, que abriram espaço para novas linhas de investigação sobre a cidade. Entre esses, destacam-se autores como Gordon Cullen, Kevin Lynch, Christopher Alexander e Amos Rapoport que apontaram para a necessidade de atenção maior para a dimensão morfológica da cidade e para a forma como a cidade é percebida pelo indivíduo.

A partir do conhecimento desenvolvido por esses autores, é possível perceber que os elementos comuns ao meio ambiente de um grupo, e que fundamentam a estruturação de suas imagens espaciais, podem ser identificados a partir do estudo morfológico do lugar que esse grupo habita. Esse estudo consiste em uma interpretação articulada que envolve tanto os elementos morfológicos entre si, como com os grupos sociais que com eles se relacionam.

Segundo Philippe Panerai (2006) a cidade não pode ser compreendida de forma independente dos grupos sociais que a produzem, que nela vivem e que a transformam. Ele sugere quatro eixos que se mostram adequados ao presente estudo: Paisagens Urbanas (1), Crescimentos (2), Tecidos Urbanos (3) e Tipologias (4) - descritos a seguir.

- Em Paisagens Urbanas (1), o autor recorre às ideias de Lynch (1982) sobre a legibilidade da cidade e da imagem mental que os cidadãos têm desta. Lynch (1982, p. 58-59) elenca cinco elementos que considera os principais definidores da imagem da cidade: vias, canais de locomoção, onde as pessoas observam a cidade em movimento; limites, elementos lineares que separam, enquanto fronteira, uma região da outra; bairros, regiões urbanas em que o observador reconhece como tendo 
um caráter comum de identificação; cruzamentos ou pontos nodais, locais estratégicos e de convergências; e elementos marcantes, objetos físicos e dotados de certa originalidade, que se destacam no contexto urbano e servem de referência para o observador. Panerai $(2006$, p. 36) também apresenta uma forma de apreensão da paisagem urbana construída por meio de uma sucessão de deslocamentos, que permitem estudar as modificações que ocorrem no campo visual durante um percurso despertado pelo sentido da visão. Esse olhar sequencial é muito similar ao que Cullen (1983) chama de visão serial.

- O eixo Crescimentos (2) é classificado em dois modos: o contínuo e o descontínuo, que estão relacionados ao crescimento linear. Panerai também apresenta como componente de análise os elementos reguladores, ou seja, aqueles que regulam o crescimento da cidade, fornecendo uma estrutura que ordena a expansão (linhas e polos) ou contenção (barreiras e limites), podendo ser naturais ou construídos (PANERAI, 2006, p. 53).

- O terceiro eixo são os Tecidos Urbanos (3), frutos da superposição ou imbricação de três conjuntos: as redes de vias, os parcelamentos fundiários e as edificações (Idem, p. 77-78). Sua análise consiste inicialmente na identificação de cada conjunto e, posteriormente, no estudo de sua lógica e relações de modo a entender a lógica da conformação e transformação dos tecidos urbanos.

- Por fim, em relação às Tipologias (4), Panerai sistematiza um método de análise tipológica, a partir dos estudos italianos, constituído de diferentes níveis e que ressalta a articulação entre eles, buscando entender como a lógica de um nível influi sobre o outro e os traços característicos de um nível que permanecem sendo pertinentes a outro. Para tal, o autor subdivide a análise em quatro fases: a definição da abrangência; a classificação prévia; a elaboração dos tipos; e a tipologia em si (ibidem, p. 127).

A partir dos quatro eixos abordados foi possível realizar análises da velha e da nova Itacuruba, o que permitiu identificar quais elementos constituem as imagens espaciais de um grupo, estruturando os seus lugares de memória e, consequentemente, a sua identidade.

\section{Metodologia de análise aplicada}

O método utilizado foi dividido em três etapas: revisão bibliográfica, análise urbana (para cada cidade, com base no referencial supracitado) e análise comparativa entre as cidades. A revisão bibliográfica visou introduzir as primeiras discussões e realizar uma aproximação com o objeto de estudo. Nela foram realizadas pesquisas e elaboradas fichas de leituras a partir de livros, teses, artigos, entre outras publicações relacionadas ao tema. Na segunda etapa foi selecionada a ferramenta de análise urbana e aplicada de forma individualizada sobre a velha e a nova cidade de Itacuruba. Ainda nesta etapa foi realizada uma visita de campo à nova Itacuruba, entre os dias 04 e 06 de outubro de 2019. Nessa visita foi possível consultar órgãos públicos, aplicar entrevistas e realizar registros fotográficos. As entrevistas duraram cerca de 1 (uma) hora cada e foram aplicadas com 15 moradores remanescentes de idade superior a 45 anos, de modo que tivessem vivenciado grande parte da infância na antiga cidade. A entrevista tomou como referência o método apresentado por Kevin Lynch (1982) e teve como produto mapas mentais (apresentados nos resultados deste artigo). A terceira e última etapa correspondeu a uma análise comparativa entre as duas cidades, a partir dos resultados obtidos na análise anterior, e que foi associada à uma interpretação do discurso da população entrevistada.

\section{CONTEXTUALIZAÇÃO}

\section{O Nacional Desenvolvimentismo e as obras de grandes impactos}

O reassentamento da cidade de Itacuruba foi um dos frutos do nacional-desenvolvimentismo vigente no Brasil entre as décadas de 1930 a 1970. Esse modelo político-econômico teve como princípio a industrialização do país, tendo o Estado como o grande condutor, por meio do planejamento regional e de investimentos estatais pesados em transporte e energia (IANNI, 1971). Foi nesse contexto que o Nordeste passou a ser alvo dos interesses governamentais, pois, a região, ao mesmo tempo que representava uma barreira para o desenvolvimento almejado, também detinha um significativo potencial de geração de energia elétrica através do aproveitamento da força motriz das águas do rio São Francisco. Para isso, foram implantadas ao longo de seu leito uma série de usinas hidrelétricas que impactaram diretamente na vida dos grupos populacionais que habitavam a região. 
Estas intervenções ficaram a cargo da Companhia Hidroelétrica do São Francisco (CHESF), que foi criada por meio do Decreto Lei no 8.031, assinado por Vargas em 03 de outubro de 1945 (BRASIL, 1945). No entanto, a deposição deste último, naquele mesmo mês, retardou em quase três anos o início das atividades da companhia ${ }^{5}$. A nova Constituição Federal (1946) elaborada no Governo do presidente Eurico Gaspar Dutra incluiu o interesse de elaborar um planejamento regional, com projetos previstos para várias regiões, entre elas o Vale do São Francisco:

Art. 29. O Governo Federal fica obrigado, dentro do prazo de vinte anos, a contar da data da promulgação desta Constituição, a traçar e executar um plano de aproveitamento total das possibilidades econômicas do rio São Francisco e seus afluentes, no qual aplicará, anualmente, quantia não inferior a um por cento de suas rendas tributárias. (Ato das Disposições Constitucionais Transitórias, BRASIL, 1946).

Em 15 de dezembro de 1948, nove meses após a Assembleia de Constituição da CHESF, foi criada a Comissão do Vale do São Francisco (CVSF) através da Lei no 541 . Essa comissão teve sua operação iniciada a partir de 1949 com a missão de contribuir para a estruturação do território brasileiro, criando na região condições favoráveis à permanência e a melhoria da qualidade de vida da população, visando dessa forma dar mais equilíbrio às regiões do país (LOPES, 1955).

Ao retornar ao poder, em 1951, Getúlio Vargas avançou no ambicioso projeto de implantação da indústria de base no país, na qual as infraestruturas de energia e transportes desempenhariam um papel fundamental. Parte deste esforço, o Plano Nacional de Eletrificação (PNE) previa a criação de empresa responsável pela realização de estudos, projetos, construção e operação de usinas, linhas de transmissão e distribuição de eletricidade, a Eletrobrás (Centrais Elétricas do Brasil).

Graças os fortes incentivos para o setor elétrico constantes no Plano de Metas de Juscelino Kubitschek, sua criação foi concretizada em 25 de abril de 1961 já no Governo João Goulart ${ }^{6}$. Ela foi instalada em 11 de julho de 1962, sendo responsável "pelos estudos, projetos, construção e operação de unidades de produção assim como das linhas de transmissão e de distribuição de eletricidade" (OLIVEIRA, 2018, p. 333).

A Eletrobrás tornou-se uma peça-chave da expansão hidrelétrica durante o Regime Militar, que deu continuidade aos planos de expansão da geração de energia através do estímulo à construção de hidrelétricas de grande porte, aumentando em cerca de 30\% da eletrificação residencial entre 1970 e 1985 (OLIVEIRA, 2018, p. 334). A construção de barragens promoveu inúmeros impactos, incluindo o reassentamento das populações ribeirinhas:

Essa maneira de proceder teve efeitos desastrosos, pois ignorou todas as relações entre essas pessoas e seu território, seu modo de vida e também o papel do tecido social para as comunidades. Além disso, o processo de indenização ele mesmo foi muitas vezes complexo, porque em várias regiões como no Norte e no Nordeste do país, as pessoas não possuíam títulos de terra. Durante o regime militar, os projetos foram implantados de forma autoritária e sem discussão com a população, que muitas vezes só eram informadas dos projetos quando os processos de expulsão começavam (OLIVEIRA, 2018, p. 339).

A distensão do Regime Militar e a organização social dos reassentados, ora associados à lgreja ora a outros movimentos sociais, fizeram com que o estado não apenas se tornasse responsável pela indenização financeira da população remanejada, mas também passasse a ofertar a ela um projeto de cidade e das respectivas habitações.

\section{A água como força motriz: as hidrelétricas do São Francisco}

O rio São Francisco possui $2.700 \mathrm{~km}$ de extensão e tem sua nascente localizada no alto do Parque Nacional da Serra da Canastra em Minas Gerais ${ }^{7}$. Ele foi um dos indutores da ocupação do território nos três primeiros séculos da colonização, mas, com a transferência da capital de Salvador para o Rio de Janeiro, começou a perder importância como o "grande caminho". No Segundo Império, a atenção para o Velho Chico voltou com os estudos e planos que visavam a sua transposição, porém, foi na virada para o século XX que o potencial de geração de energia elétrica passou a ser visto como um importante meio para solucionar os problemas de abastecimento elétrico do país (CAMELO FILHO, 2018, p. 84).

A partir de 1920 foram realizados estudos por parte do Ministério da Agricultura que identificaram a possibilidade de implantação de grandes hidrelétricas na região, mas só com a forte crise energética de 1940, provocado pelo processo de urbanização e industrialização, é que o potencial energético do rio São Francisco passou a ser seriamente considerado (OLIVEIRA, 2018, p. 322).

A primeira grande usina construída na região Nordeste pela CHESF foi a de Paulo Afonso, cuja inauguração aconteceu em 1955'. Na década de 1960 ela foi seguida pela Usina de Paulo Afonso II (BRANDI, s/d), 
iniciando, assim, um período de obras com proporções inéditas, que visavam assegurar energia para uma vasta porção do país até então precariamente eletrificada.

Em 1971 a CHESF inaugurou a Usina de Paulo Afonso III e prosseguiu com a construção de mais cinco usinas hidrelétricas: Moxotó (Apolônio Sales) e Paulo Afonso IV, completando o complexo Hidrelétrico de Paulo Afonso; Sobradinho, seguida pela de Itaparica (Luiz Gonzaga) e Xingó. Totalizam, assim, oito (8) usinas hidrelétricas instaladas no rio São Francisco sob responsabilidade da CHESF. Com as usinas de Três Marias, Retiro Baixo e Queimado sob responsabilidade da Companhia Energética de Minas Gerais (CEMIG), o conjunto soma 11 (onze) usinas hidrelétricas que hoje exploram o potencial hídrico do rio.

\section{A usina hidrelétrica de Itaparica e a proposta de reassentamento}

A Usina Hidrelétrica de Itaparica (Luiz Gonzaga), possui um reservatório com uma área de $828 \mathrm{~km}^{2}$ e está localizada no polígono das secas, entre Pernambuco e Bahia. A decisão para construção de mais uma Hidrelétrica na região se deu, de acordo com Dias (1988), a partir do reconhecimento de que as usinas existentes ou em construção seriam insuficientes para atender as demandas de abastecimento elétrico previstas para a região Nordeste. Para tal, foi construída a Usina de Sobradinho entre 1973 e 1979, seguida da Usina de Itaparica, cuja obra tive início em julho de 1979.

Entre os principais obstáculos a serem resolvidos para a construção, estava o reassentamento da população que habitava a região. Sete municípios foram parcialmente atingidos pela inundação do reservatório de Itaparica: Petrolândia, Floresta, Itacuruba e Belém do São Francisco, no estado de Pernambuco, e os municípios de Glória, Rodelas e Chorrochó na Bahia. Três sedes municipais - Petrolândia, Itacuruba e Rodelas - bem como o povoado de Barra do Tarrachil, tiveram que ser reassentados. De acordo com a CHESF (1986), isso correspondeu a um total de 35.905 habitantes a serem reassentados, sendo 14.745 domiciliados na zona urbana e 21.160 na zona rural (Figura 1).

Figura 1: Região de influência do Reservatório de Itaparica e tabela das famílias e pessoas cadastradas por município.

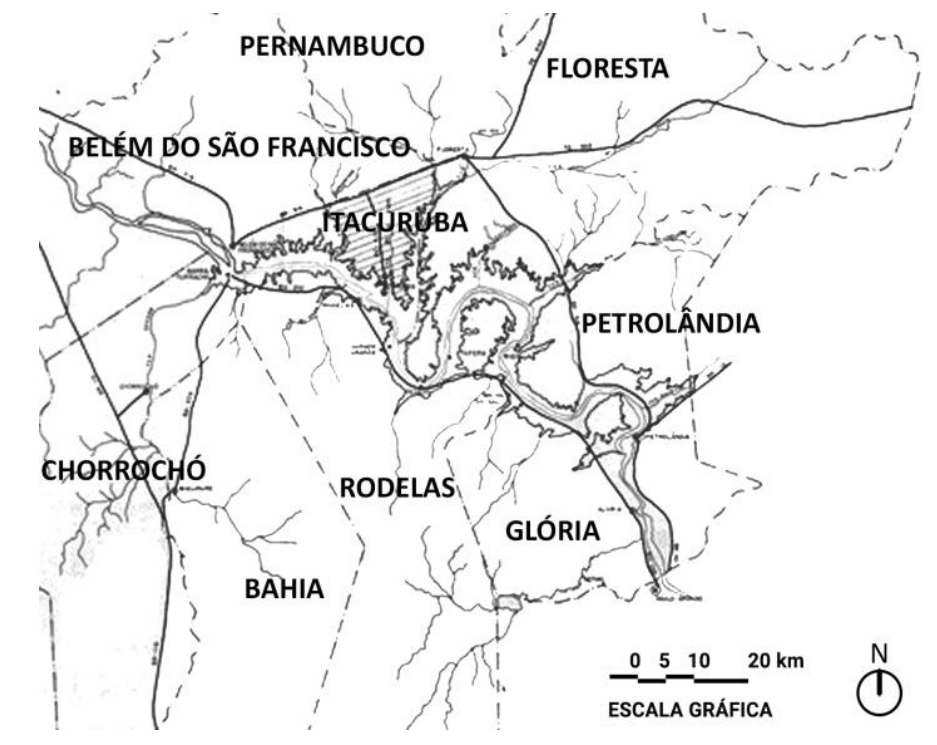

\begin{tabular}{|l|c|c|c|c|c|c|}
\hline \multirow{2}{*}{ MUNICÍPIOS } & \multicolumn{2}{|c|}{ TOTAL } & \multicolumn{2}{c|}{ ZONA URBANA (1) } & \multicolumn{2}{c|}{ ZONA RURAL } \\
\cline { 2 - 7 } & FAMILIAS & PESSOAS & FAMIILIAS & PESSOAS & FAMÍLIAS & PESSOAS \\
\hline MARGEM ESQUERDA (PE) & $\mathbf{5 . 5 4 2}$ & $\mathbf{2 6 . 9 4 0}$ & $\mathbf{2 . 4 5 0}$ & $\mathbf{1 0 . 8 7 8}$ & $\mathbf{3 . 0 9 2}$ & $\mathbf{1 6 . 0 6 2}$ \\
\hline Belém São Francisco & 681 & 3.540 & - & - & 681 & 3.540 \\
\hline Floresta & 702 & 3.675 & - & - & 702 & 3.675 \\
\hline Itacuruba & 1.050 & 5.357 & 380 & 1.854 & 670 & 3.503 \\
\hline Petrolândia & 3.190 & 14.368 & 2.070 & 9.024 & 1.039 & 5.344 \\
\hline MARGEM DIREITA (BA) & $\mathbf{1 . 8 3 6}$ & $\mathbf{8 . 9 6 5}$ & $\mathbf{7 5 4}$ & $\mathbf{3 . 8 6 7}$ & $\mathbf{1 . 0 8 2}$ & $\mathbf{5 . 0 9 8}$ \\
\hline Chorrochó & 403 & 2.024 & 284 & 1.468 & 119 & 556 \\
\hline Glória & 312 & 312 & - & - & 312 & 1.431 \\
\hline Rodelas & 1.121 & 1.121 & 470 & 2.399 & 651 & 3.111 \\
\hline TOTAL & 7.378 & 35.905 & 3.204 & 14.745 & 4.174 & 21.160 \\
\hline \% & - & - & 43,42 & 41,06 & 56,57 & 58,93 \\
\hline \\
FONTE: CHESF -DIR - Cadastramento de Famílias 1984. \\
(1) No município de Chorrochó, a localidade Barra do Tarrachil foi considerada urbana.
\end{tabular}

Fonte: Os autores (2019), com base em CHESF (1981 e 1986). 
O Plano de Implantação elaborado pela CHESF incluiu a intenção de garantir boas condições de vida à população reassentada e o reconhecimento de que se deveria prover uma indenização justa pelas terras, edificações e outras benfeitorias localizadas na área inundada. Para o reassentamento, os planos urbanísticos previam infraestrutura de água, saneamento, eletricidade, habitações e edificações para serviços públicos, comunitários e religiosos (CHESF, 1986, p. 3).

A forte resistência da população ao reassentamento acarretou sucessivos adiamentos para conclusão da obra da Usina de Itaparica. Em 1986, a população ocupou o canteiro de obra da usina, impedindo por seis dias o seu funcionamento, o que gerou o "Acordo de 86" que garantia aos reassentados boas terras para irrigação e criatório, moradia, assistência técnica, verbas de manutenção temporária, justas indenizações e participação efetiva nas decisões do reassentamento (FIGUEIREDO, 2011).

Itacuruba foi a cidade mais atingida pelo reservatório, visto que quase um terço do seu território ficou submerso. O processo de reassentamento dessa cidade foi relatado no documentário De Profundis (2014), que sintetiza bem os impactos provocados à saúde mental de sua população. Nele, é possível ver o momento em que os habitantes deixam suas terras, em uma procissão levando a imagem de Nossa Senhora do Ó em direção à nova cidade, como relatado por um dos reassentados no filme: "Foi difícil para todo mundo. Tanto choravam os grandes, como choravam os pequenos" (Figura 2).

Figura 2: A saída da população da velha Itacuruba. Acervo dos moradores da velha cidade.

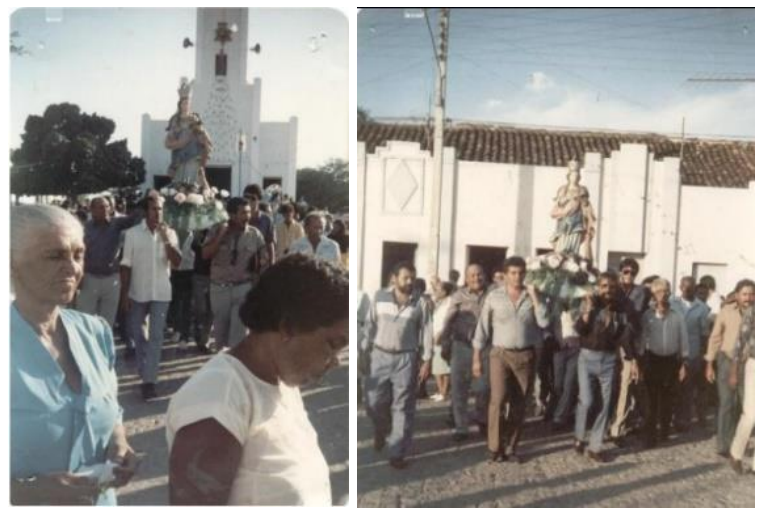

Fonte: Figueiredo (2011)

Hoje, chama a atenção os dados estatísticos apresentados pelo Conselho Regional de Medicina de Pernambuco - CREMEPE, nos quais Itacuruba aparece como uma das cidades brasileiras que mais se utiliza de antidepressivos, chegando a alcançar o maior índice de suicídio do país, tornando-se conhecida como "a cidade dos depressivos", causados, segundo o CREMEPE, pela "perda de terras férteis, da agricultura como base produtiva, de referências simbólicas e ancestralidade" 9 .

\section{A VELHA ITACURUBA}

Assim como as demais cidades reassentadas para construção da Usina de Itaparica, Itacuruba se desenvolveu tradicionalmente às margens do rio São Francisco. A cidade foi fundada em 1870 como um ponto de apoio para tropeiros e boiadeiros. Em 1889, foi concluída a sua igreja nas margens do rio para abrigar a imagem de Nossa Senhora do Ó, colhida por pescadores após ter sido levada da capela construída por capuchinhos franceses nos primórdios do século XVIII, em uma das ilhas do São Francisco, durante uma enchente que inundou toda a IIha (FIGUEIREDO, 2011, p. 35-36).

A velha Itacuruba tinha uma implantação espontânea, integrada com a topografia e baseada em uma lógica de ocupação linear típica das cidades das margens do rio São Francisco (Figura 3). De acordo com Panerai (2006, p. 61), as linhas de expansão revelam características do sítio ao qual estão inscritas, assim como as tensões em diferentes escalas e tempos.

Para Figueiredo (2011, p. 39), essa proximidade com o rio fazia a população sentir-se diferente diante dos demais sertanejos da caatinga que sofriam com as terras secas no interior. Ali, nas margens do São Francisco, eles viviam uma vida de fartura de água, com terras férteis e agricultáveis: 
Eram várias ilhas, várias, e tínhamos o rio bem valente, bem forte, e também tínhamos como trabalhar, tínhamos a parte da agricultura bem presente em nossas vidas. Éramos conhecidos como um povo da cebola, que plantava muita cebola (Entrevistada 01).

[...] lá a gente tinha uma enormidade de alimentos na porta da gente, tinha todo tipo de fruta, tinha feijão, a vaca que dava o leite, o pé de manga, frutas, os legumes, ninguém passava necessidade por falta desse tipo de alimento (Entrevistada 05).

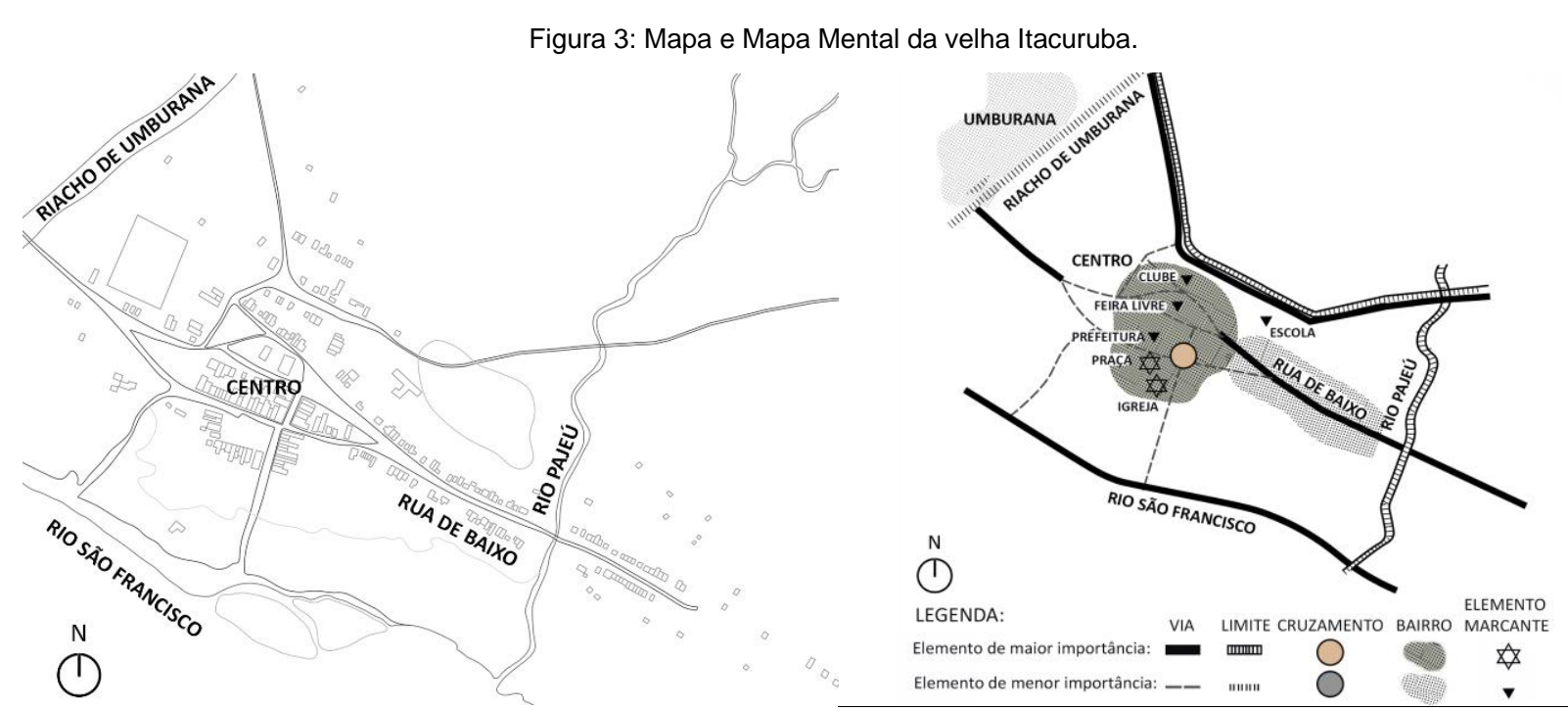

Fonte: Os autores - mapa adaptado de CHESF (1986) e mapa mental de autoria própria (2019).

O rio pode ser visto como uma linha de força de Cullen: “...certas linhas de força que representam igualmente uma combinação de circunstâncias que estiveram na origem da cidade" (1983, p. 113). Considerando as vias como elementos definidores da imagem da cidade, percebe-se que o rio São Francisco desempenhava esse papel, visto que o transporte fluvial era de grande importância para a população, interligando-os às suas ilhas e à cidade de Rodelas, na Bahia. Foi devido a presença do "Velho Chico" que a cidade de Itacuruba tomou essa conformação. O traçado urbano surgiu tendo o rio como referência, e foi voltado para ele que a lgreja de Nossa Senhora do Ó foi edificada. Portanto, o "Velho Chico" era de grande importância para a cidade, que parece "constituir um local de eleição, pela qualidade imediata da vista que proporciona sobre paisagem" (CULLEN, 1983, p. 26):

[...] a gente tinha uma paisagem linda para apreciar, e rica, que eram duas paisagens em uma só, por conta do rio São Francisco e as ilhas. Elas se tornavam uma paisagem encantadora quando era de tardezinha, no anoitecer era muito bonito você apreciar o rio, a ilha (Entrevistada 07).

As entrevistas revelam o quão importante era o rio para os moradores. Quando questionados sobre o lugar na velha Itacuruba que vinha à mente, o rio São Francisco esteve presente em todas as respostas. Além do rio, alguns eixos de circulação terrestres também possuíam um importante papel na cidade, promovendo a comunicação de Itacuruba com as cidades vizinhas (Figura 4).

Figura 4: O rio São Francisco e suas margens. Fotos do acervo de moradores da velha cidade.
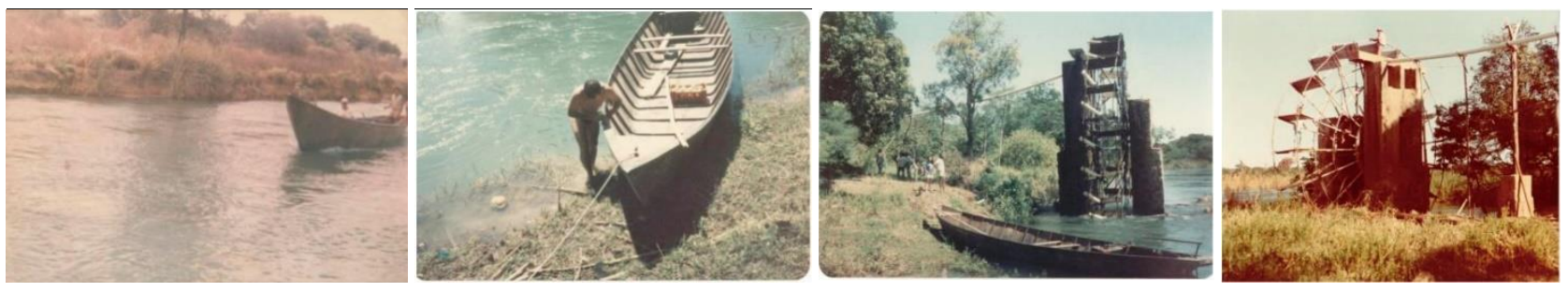

Fonte: Figueiredo (2011)

A conformação espacial de seu centro remete às formações urbanas tradicionais coloniais, quando as formas das ruas eram definidas a partir da disposição dos elementos edificados. Apesar de formalmente inexistirem bairros, os entrevistados identificavam três regiões, cada uma com sua identidade: "Rua de Baixo", Umburana 
e Centro. Essas unidades detinham densidades e formas de ocupação diferenciadas que contribuíam para "realçar a força temática de cada uma" (LYNCH, 1982, p. 84). Para Cullen (1983, p. 9), a justaposição desses diferentes elementos é que atribui vida à cidade.

Os cruzamentos (pontos nodais para Lynch ou polos de crescimento para Panerai) da cidade de Itacuruba se localizavam na área central, local estratégico onde se concentravam os principais equipamentos. A Praça e a Igreja eram os elementos chave que marcavam simbolicamente o centro da cidade, servindo como referência para o observador. A igreja era um marco não apenas pela sua arquitetura, mas também pela sua importância para a história da cidade (Figura 5). Herdeiras diretas da tradição arquitetônica do período colonial, as casas da velha Itacuruba seguiam o mesmo padrão de simplicidade da igreja, com paredes grossas de alvenaria, alcovas e corredores. As técnicas construtivas eram rudimentares e os acabamento rústicos. As coberturas de telha canal de duas águas lançavam a água da chuva ora parte sobre o quintal, e a outra parte sobre condutores ou calhas na fachada frontal. A pesquisa conduzida pela CHESF identificou que $96 \%$ das habitações eram consideradas de qualidade precária, baixa e regular, e cerca de dois terços não possuíam instalações hidráulica e sanitária (Figura 6).

Figura 5: O centro da velha Itacuruba e sua igreja.

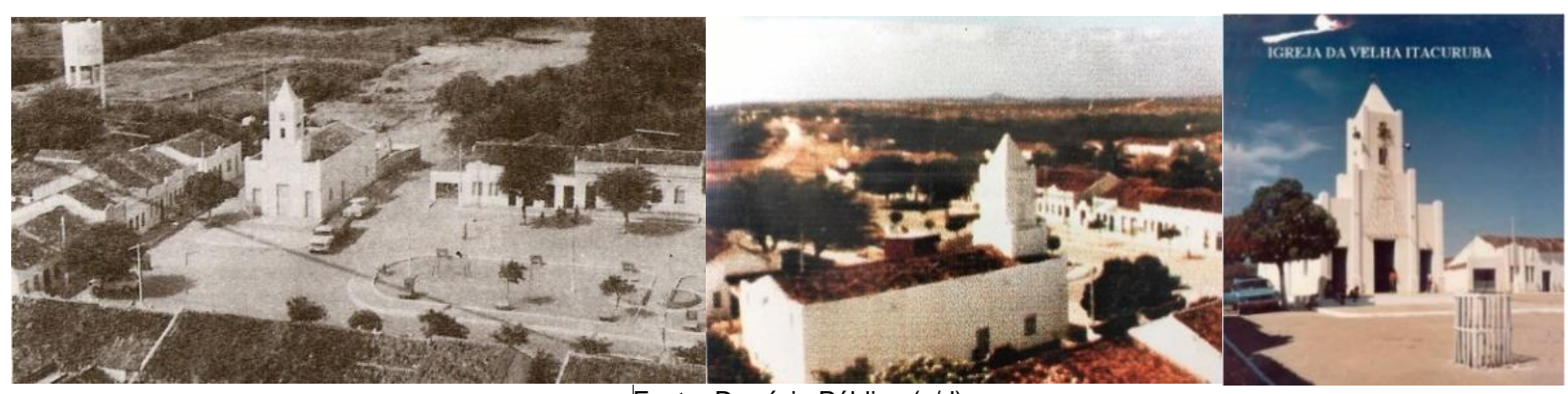

Fonte: Domínio Público (s/d).

Figura 6: As casas da velha Itacuruba.

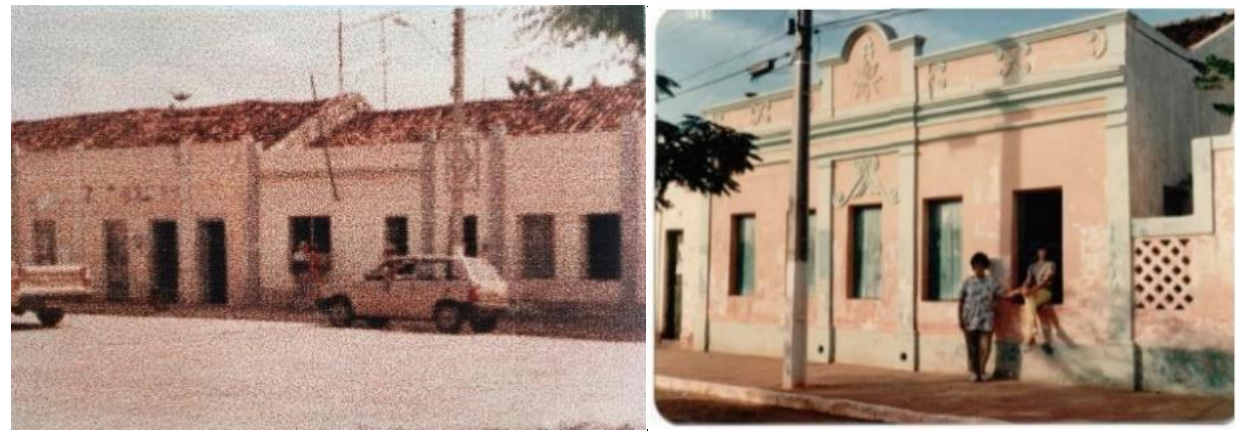

Fonte: Domínio público (s/d) e Figueiredo (2011), respectivamente.

Em suma, a velha Itacuruba era uma cidade cuja origem de ocupação e lógica de crescimento estavam fundamentalmente atreladas ao rio São Francisco. O traçado urbano era de cariz colonial, articulado a partir de dois elementos: a Praça e a Igreja, os mais visíveis para a população.

\section{A NOVA ITACURUBA: A CIDADE MODERNA}

O Plano Urbanístico da nova cidade de Itacuruba foi elaborado em 1986 pela Secretaria de Habitação (SEHAB) do estado de Pernambuco, sendo coordenado pelo arquiteto Silvio Granville Costa. O princípio da participação popular seria pilar básico nesse processo, provendo condições mais favoráveis ao bem-estar da população e novas oportunidades de acesso à moradia, saneamento básico e integração aos serviços. No Plano também consta que foram levados em consideração as características existentes, visando atender os aspectos culturais e as relações comunitárias do antigo núcleo urbano.

O Estudo de Alternativa de Sítio para o Novo Núcleo Urbano de Itacuruba (1981), elaborado pela CHESF, apresenta três alternativas de sítio que buscaram: manter a maior proximidade da cidade atual, garantindo a 
mesma posição em relação à água, isto é, nas margens do lago; facilitar a maior proximidade das demais sedes urbanas da região, no caso Floresta e Belém do São Francisco; e aproximar a cidade de zonas com maior possibilidade de exploração agrícola.

O sítio foi escolhido, segundo a CHESF (1981), por meio de um plebiscito realizado pela Prefeitura da cidade, que apontou para uma área, mas não determinou precisamente a localização. Portanto, a decisão final terminou ficando a cargo da assessoria da SEHAB-PE, da Câmara Municipal e do Prefeitura. Foi escolhido um sítio a cerca de $20 \mathrm{~km}$ da antiga sede municipal, próximo à BR-316 (cerca de $12 \mathrm{~km}$ ) e próximo da margem esquerda do rio Pajeú. Esta decisão foi firmada por meio do Decreto Estadual no 9.648 de setembro de 1984, que declarou a área de 400 ha de utilidade pública e deixou a responsabilidade da desapropriação para a CHESF (Figura 7).

Figura 7: Alternativas de Sítio para a nova Sede Municipal de Itacuruba e Sede Escolhida.

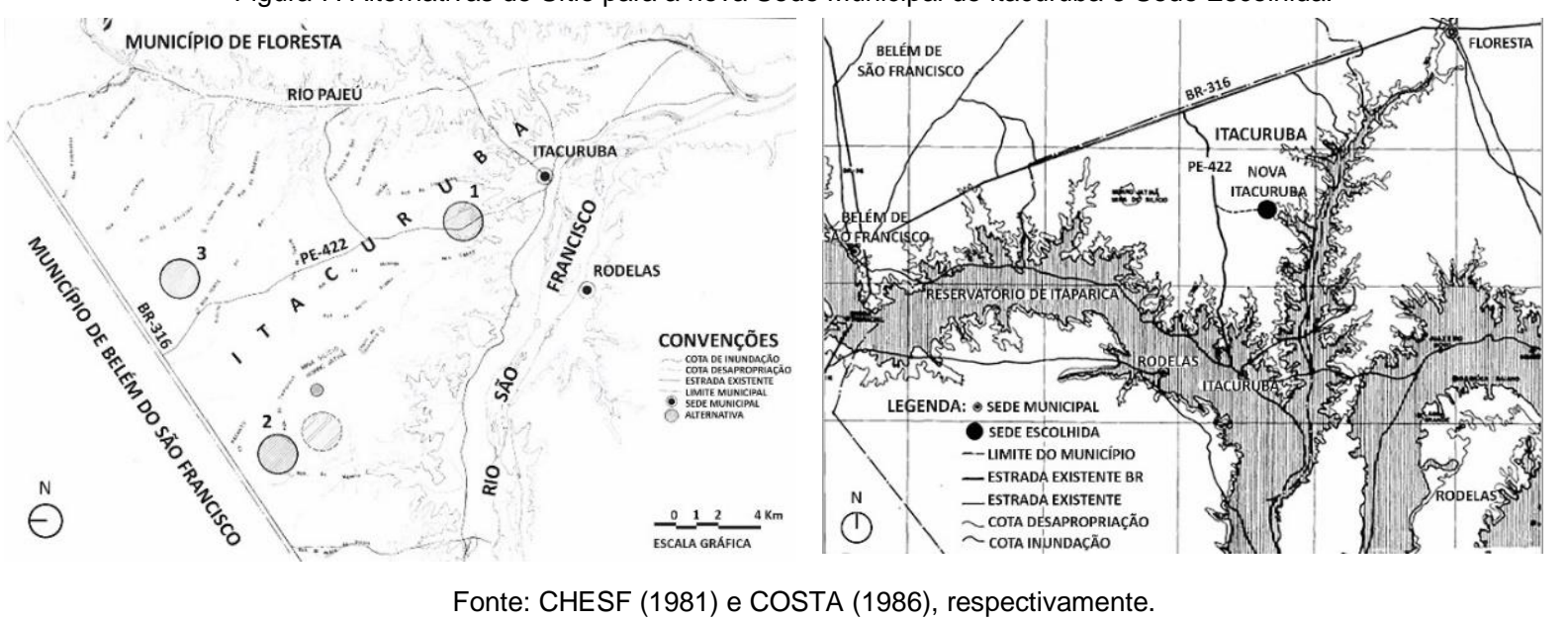

Os três critérios da indicação de sítio não foram atendidos, tendo em vista que: a cidade planejada não fica nas margens do lago; não tem conexão rápida com as demais sedes urbanas, pois é preciso percorrer cerca de 12 km pela PE-433 até encontrar a BR-316, que dá acesso às outras cidades; e a zona de apoio agrícola não foi contemplada. Além disso, a participação popular foi ignorada em seu momento final, já que a decisão ficou a cargo dos órgãos governamentais.

O plano para a nova Itacuruba (Figura 8) foi concebido apenas para a zona urbana.
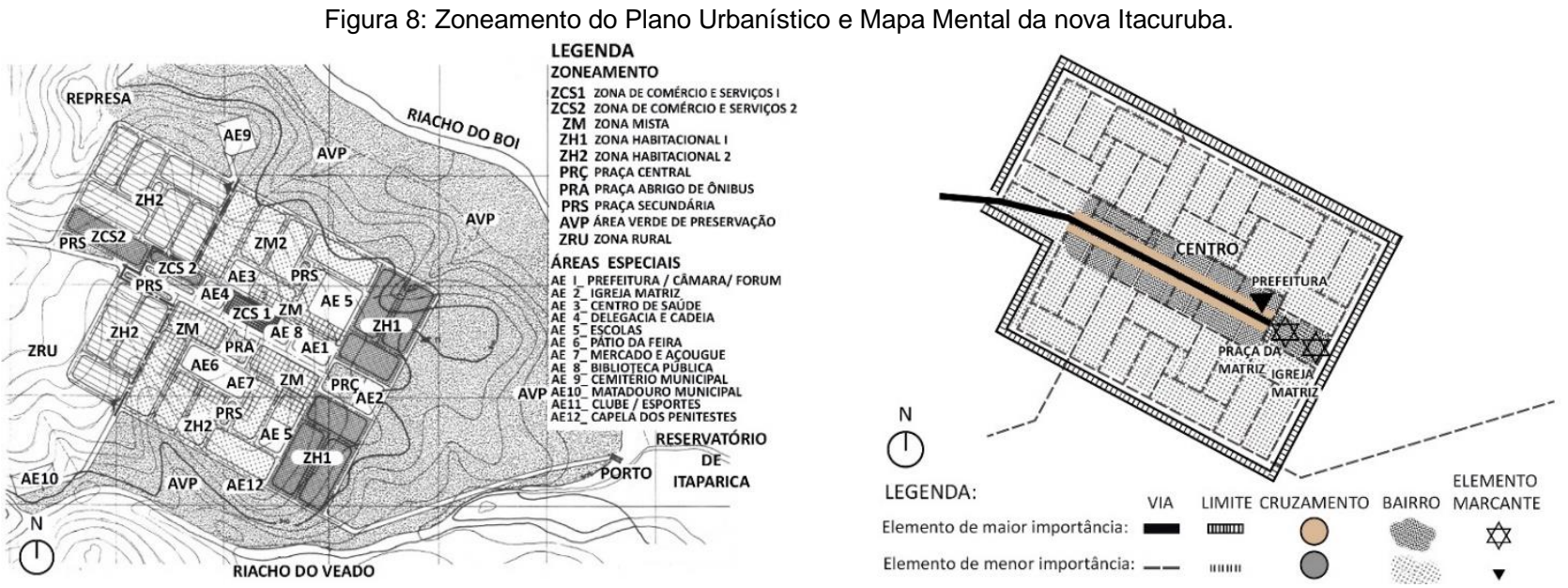

Fonte: Adaptado de COSTA (1986) e Autoria própria (2019), respectivamente.

O plano de irrigação e dos lotes rurais "destinados a formar um cinturão verde, em condições de garantir o abastecimento de hortifrutigranjeiros da nova cidade" (COSTA, 1986, p. 20) não foram implementados. A zona urbana da nova cidade ocupa parte de um platô compreendido entre dois riachos: o riacho do Boi e o riacho do Veado, que desaguam no reservatório. Em uma topografia favorável à drenagem natural, ocupação e ventilação, o plano foi desenvolvido a partir de um zoneamento contendo: duas zonas de comércio e serviço, uma zona mista, duas zonas habitacionais, três praças (Praça Central, Praça Abrigo de Ônibus e Praça 
Secundária), Zona Verde de Preservação, Zona Rural e uma Zona de Expansão Habitacional. Além disso, conta com 12 zonas especiais com os seguintes equipamentos: Prefeitura / Câmara / Fórum (AE1), Igreja Matriz (AE2), Centro de Saúde (AE3), Delegacia e Cadeia (AE4), Escolas (AE5), Pátio da Feira (AE6), Mercado e Açougue (AE7), Biblioteca Pública (AE8), Cemitério Municipal (AE9), Matadouro Municipal (AE10), Clube / Esportes (AE11) e a Capela dos Penitentes (AE12).

Em um contexto da tábula rasa, sem um histórico de crescimentos (de acordo com Panerai) e sem construções prévias, a proposta se desenvolveu privilegiando o sistema viário, que foi hierarquizado em três tipos de vias. A via principal, constitui o eixo mais importante com largura total de 18 metros e se conecta diretamente à PE-433, representando quase como uma extensão dela dentro da própria cidade. As vias secundárias têm largura de 10 metros, partindo da via principal e envolvendo uma malha de macro quadras residenciais. Por fim, as vias locais e internas das macro quadras possuem uma largura de 8 metros.

Na nova cidade os moradores não conseguem reconhecer diferenciações no espaço para além do centro. As parcelas e edificações também possuem formas retangulares, padronizadas e distribuídas quase que simetricamente. Essa homogeneidade foi incapaz de gerar imagens distintas, um dos elementos para o bom desenho urbano, segundo Lynch (1982). Correspondendo ao cruzamento dos dois eixos viários principais, a área central tem como elemento marcante a Igreja Matriz que se destaca pela localização ao fim do eixo principal, diante de sua bifurcação, e pelo fato de estar emoldurada por uma praça (Figura 9).

Figura 9: O centro da nova Itacuruba e a sua igreja.

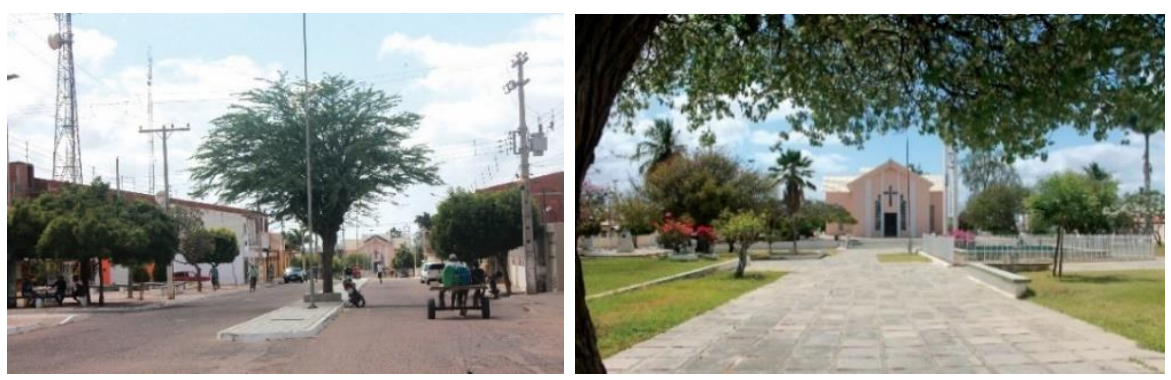

Fonte: Os autores (2019).

A definição do projeto arquitetônico das casas tomou como base a análise das características das habitações da época, o modo de vida dos moradores, em relação ao convívio proposto no plano urbanístico, assim como as aspirações manifestadas pela população. Além disso, buscou-se atender às seguintes questões: 1) Vincular a casa aos lotes; 2) Definir vários tipos de lotes para residências, com áreas de 192 a $540 \mathrm{~m}^{2}$; 3) Elaborar projetos arquitetônicos com áreas variadas, evitando uma taxa de ocupação superior a 50\% para o conforto da habitação; 4) Melhorar as instalações de conforto, fornecendo água potável, saneamento e eletricidade; 5) Introduzir variação para evitar conjuntos homogêneos, monótonos e estáticos; 6) Atender aos padrões existentes (precário, baixo e regular), definindo três tipos de acabamento; 7) Baixar o custo de manutenção, empregando materiais de construção existentes na região (CHESF, 1986, p. 69).

De acordo com o Plano, a reposição das habitações contou com algumas dificuldades, como a pouca capacidade de investimento e de empreendimento da população, a deficiência de mão de obra e a inexistência de materiais de construção no local. A nova habitação é isolada no terreno, com recuo nos quatro lados do lote. A sua volumetria parte de um retângulo, com reentrâncias em três esquinas. Da sala parte uma circulação central a partir da qual estão distribuídos três quartos e a cozinha, se conectando em seu fim com o banheiro. A cobertura foi pensada em duas águas, sem a presença de calhas. Os lotes eram demarcados por muros baixos, com altura de um metro, garantindo a permeabilidade visual (Figura 10).

Figura 10: Modelo Habitacional da nova Itacuruba.
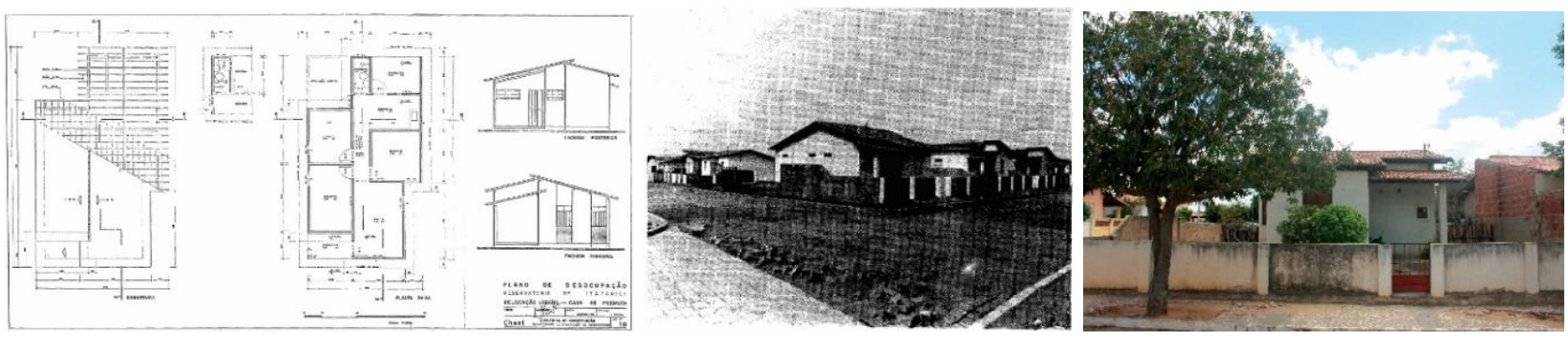

Fonte: CHESF (1986) e registro fotográfico dos autores (2019), respectivamente. 


\title{
7 OS IMPACTOS DO PLANO: UM OLHAR PARA ALÉM DOS ASPECTOS MORFOLÓGICOS
}

Uma análise comparativa entre a conformação urbana da velha e a nova cidade de Itacuruba revelam as diferenças morfológicas, um passo importante para que se possa entender, junto às entrevistas, as atribuições simbólicas que fazem de determinado espaço, um lugar; e de elementos comuns do cotidiano, uma hierofania. Por meio da correlação desses diferentes aspectos, materiais e imateriais, é possível compreender quais rupturas foram provocadas e os seus impactos à população reassentada.

De imediato, é clara a diferença dos sítios das duas cidades: uma ribeirinha e outra catingueira. A velha Itacuruba estava fundamentalmente atrelada às margens do rio, um lugar de memória pois contém os três aspectos essenciais abordados por Nora (1993): material, funcional e simbólico. O rio São Francisco é uma representação clara de uma hierofania, contendo valor simbólico enquanto manifestação do sagrado, como indica o relato a seguir, quando a entrevistada foi questionada sobre o que a fazia lembrar da antiga cidade:

\begin{abstract}
A praça. A praça e o rio. O rio principalmente. Porque assim, você ter a natureza em sua vida é tudo. Você amanhece o dia e você sabe que você tem uma coisa que Deus presenteou a gente. É porque tem lugares que tem esse presente e outros não. Nós estamos aqui e nós não temos esse presente, e tão próximo. Porque o rio está a $12 \mathrm{~km}$ da gente. E nós tínhamos o rio na beira, na porta da casa da gente. Tínhamos uma coisa que foi tirada da gente (Entrevistada 01).
\end{abstract}

Se "a manifestação do sagrado funda ontologicamente o mundo" (ELIADE, 1992, p. 17), a velha Itacuruba junto ao rio era um lugar seguro, capaz de orientar a vida de seus habitantes. Agora, as pessoas não passam pela cidade, elas vão à nova Itacuruba, já que esta está situada a aproximadamente 12 km tanto da BR-316 como do rio, não se conectando diretamente a nenhuma outra cidade. A principal via da nova cidade, diferentemente da antiga, se restringe à própria cidade. São escalas diferentes das vias principais: na antiga cidade a via tinha uma abrangência regional e na nova é local. Na antiga cidade a posição era marginal enquanto na nova cidade ela assume a centralidade. Estas transformações impactaram diretamente na vitalidade da nova cidade. Hoje, a cidade de Itacuruba vive um exílio.

A velha Itacuruba possuía uma forma tradicional claramente adaptada ao sítio e à paisagem. $\mathrm{O}$ traçado da nova cidade, por sua vez, foi concebido como uma tabula rasa, desconsiderando as particularidades do sítio. As novas edificações, isoladas no lote, não mais conformam o traçado das ruas e esse fator impacta diretamente na relação de seus habitantes com o espaço público. Na velha Itacuruba, a rua era vista por seus moradores como uma extensão da casa. As calçadas eram bastante utilizadas, conforme relatou um dos entrevistados: "...você podia ficar no meio da rua e tudo, era uma cidade tranquila, não tinha violência" (Entrevistado 02). É esse afeto que parece faltar nos moradores da nova Itacuruba com a nova cidade. A análise dos relatos das entrevistas, apesar de reconhecerem melhorias na infraestrutura, apontam para uma possível falta de identificação do grupo ao espaço construído, como atesta o seguinte trecho:

O governo nos colocou aqui, a cidade é bonitinha, como vocês estão vendo [...] apenas fizeram a cidade linda aí, é bonitinha. A velha Itacuruba [...] não tinha essa estrutura, esse planejamento da nova Itacuruba. Realmente a Itacuruba nova é tudo muito planejado. Foi um projeto novo. Então é uma cidade bonita, cidade modelo. Mas a beleza da cidade é em relação à estrutura, os prédios, realmente. [...]. A velha cidade realmente não tinha esses prédios, esses instrumentos. Em relação à estrutura, prédio, planejamento, aqui a nova ficou muito mais bonita [...]. Mas o prejuízo da gente é muito grande. Itacuruba tem hoje um índice de depressão muito grande (Entrevistada 04).

Percebe-se na fala de seus moradores que "o sentimento de apropriação do novo espaço não se consolidou, os sentimentos remetem a perdas irreparáveis, desânimo e falta de rumo" (Figueiredo, 2011, p. 139). Um dos entrevistados usou termos como "desastre" e "miserabilidade infeliz" ao falar de sua vivência na nova cidade, ressaltando o sentimento de constrangimento por não haver, segundo ele, "expectativa de vida".

É possível perceber no discurso dos moradores que a falta de identificação está muitas vezes atrelada ao aspecto econômico, visto que na cidade antiga a vida econômica estava profundamente interligada às atividades agrícolas nas margens do rio. Os altos níveis de depressão podem estar associados a ausência de uma vida economicamente ativa:

[...] Mas meus avós tinham terra, não receberam nenhuma. Até hoje meus avós não receberam nada. Então meu avô não aguentou, logo que chegou aqui, viemos para cá em 88. Em 89 meu avô morreu, do coração. E morreu com muita raiva. Porque tiraram tudo, ele era marchante, questão de carne, ele tinha casa de farinha, ele era agricultor, tinha muitos filhos, muitos netos e tiraram tudo dele. Nós tínhamos muitos casebres em Itacuruba, realmente precisávamos ter uma qualidade de vida melhor lá, só que a CHESF deu essa parte aqui na nova cidade, mas não olhou o lado da gente sobreviver no dia a dia (Entrevistada 03). 
A cidade de Petrolândia, também reassentada para a construção da Usina Hidrelétrica de Itaparica, tinha a agricultura como um dos pilares da economia, mas teve seu projeto de irrigação implementado. No entanto, os seus índices de depressão são tão elevados quanto os de Itacuruba, indicando que talvez os fatores que ocasionaram a depressão não estão estritamente ligados à atividade econômica, abrangendo, também, questões de cunho subjetivo como a própria identificação espacial aqui estudada.

Outro aspecto importante em algumas das falas dos entrevistados foi o sentimento de medo, mesmo diante de índices baixíssimos, quase nulos nas principais estatísticas de criminalidade obtidos pela nova cidade. Cabe questionar, portanto, o que significa esse medo. Para Lynch (1982), o medo advém do sentimento de desorientação, que se dá em um meio ambiente que carece de legibilidade. Na percepção de Eliade, "Toda destruição de uma cidade equivale a uma regressão ao Caos" (1992, p. 29). Para Halbwachs (1990), as razões para esse medo podem residir na sensação de estar perdido em um meio estranho, sem apoio e de ser incapaz de reconhecer objetos familiares diante da destruição das imagens espaciais.

$O$ reassentamento expôs os habitantes à insegurança e incerteza. A memória coletiva da população perdeu sua dimensão espacial, ou seja, as imagens espaciais (HALBWACHS, 1990) que estruturam seu quadro de referências (POLLAK, 1989), visto que, em muitos aspectos, a constituição morfológica da nova cidade rompeu com a antiga. Na nova cidade, as calçadas passaram a ser um espaço rejeitado; as ruas desertas expressam o ato de voltar-se para dentro. Se na antiga cidade os espaços preferidos da população eram os espaços públicos, hoje o espaço preferido pelos entrevistados é a própria casa, o que se reflete nos altos muros construídos, que negam o espaço público e aprofundam a falta de identificação com a nova cidade (Figura 12).
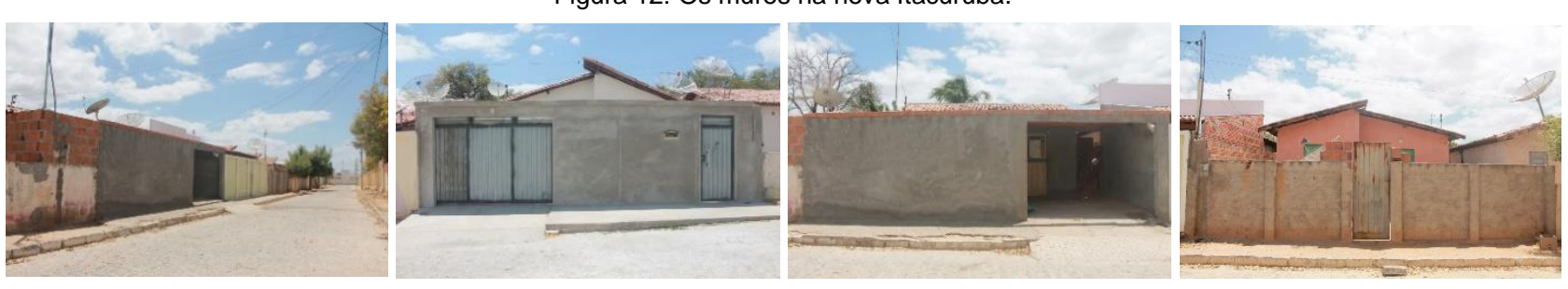

Fonte: Os autores (2019).

No que concerne a paisagem urbana, também é válido apontar a diferença entre o espaço heterogêneo da antiga cidade versus a homogeneidade da nova cidade. $\mathrm{Na}$ antiga cidade, apesar de não haver uma delimitação formal, era possível aos seus habitantes reconhecerem a existência de bairros. Na nova cidade, apenas o centro é reconhecido. Os entrevistados relataram dificuldade para compreender espaços diferentes. O novo desenho urbano não contribui para isto, como provado em um estudo de visão serial feito no local. A relação dos habitantes com a praça e a igreja, lugares de memória, foi também transformada, como revela uma das entrevistadas quando questionada sobre o que costumava fazer na antiga cidade:

[...] Nós tínhamos uma pracinha que eu vou mandar pra você, que também era um local pra noite, para a gente estar. Era um local a noite que a gente se reunia. Aqui se reúne né, tem essa, tem aquela ali. Lá só tinha uma, então todo mundo vinha pra aquele local. Então todo mundo se encontrava com mais facilidade. Hoje vive uns ali, outro aqui, então é mais difícil encontrar todo mundo no mesmo lugar. Por mais que a cidade seja pequenininha (Entrevistada 01).

Se na velha Itacuruba existia uma única praça e essa exercia plenamente o seu papel enquanto espaço de trocas e encontros, a existência de mais de uma praça na nova cidade provocou certa dispersão da população. Se na velha Itacuruba a igreja se anunciava enquanto ponto focal e elemento marcante pela sua configuração e verticalidade, na nova cidade ela perder sua posição de um elemento vertical marcante, visualizado a longa distância, e ficou minimizada frente aos novos eixos viários.

\section{CONSIDERAÇÕES FINAIS}

A pesquisa mostrou que a relação entre arquitetura, urbanismo e saúde mental se configura no sentimento de identidade. Do ponto de vista espacial essa identidade se constrói quando o grupo se relaciona com os elementos de seu entorno por meio das imagens espaciais (HALBWACHS,1990) que conformam um quadro de referências (POLLAK, 1989) e estruturam a memória coletiva enquanto lugares de memória (NORA, 1993) - todos entendidos como partes integrantes do sentimento de identidade (POLLAK, 1992). 
Um importante ponto de partida para a construção desse vínculo com o lugar está fundamentado no seu entendimento enquanto manifestação do sagrado - uma hierofania, para Eliade (1992), ou, simplesmente, uma atribuição simbólica aos objetos que estão ao nosso redor, para Halbwachs (1990). Essa visão sacralizada/simbólica é um referencial para o grupo e atribui sentido existencial a ele. Consequentemente, uma possível ruptura dessa relação provoca desorientação e incertezas. Sob essa perspectiva, as ferramentas de análise da forma urbana permitiram entender os elementos espaciais com maior força na estruturação da identidade de um grupo.

No caso estudado, o resultado da análise mostrou que a principal ruptura residiu na quebra de vínculo da cidade com o rio São Francisco - antes ribeirinha e hoje catingueira. O rio era o elemento estruturador da cidade por ser lugar de memória e uma representação clara de uma hierofania. A cidade surgiu em decorrência da existência do rio, estando a ele atrelado suas práticas e costumes. As relações que Itacuruba mantinha com os municípios vizinhos também foram prejudicadas, visto que a nova cidade não se conecta diretamente a nenhuma outra. $O$ plano da nova cidade também rompeu em vários aspectos com a cidade anterior. O traçado das vias, antes orgânico e hoje ortogonal; a dimensões de se pensar a cidade, na antiga em volumetria e na nova enquanto plano; e a relação entre arquitetura e morfologia urbana, antes com edificação colada no limite do terreno e hoje solta no lote.

Essas rupturas impactaram diretamente a forma de viver a cidade de Itacuruba e, por conseguinte, a vida de seus moradores. As patologias no campo da saúde mental - com os elevados índices de depressão e suicídio - podem ser interpretadas como consequência da perda desses referenciais identitários. Essa falta de identificação provoca um sentimento de medo que não se justifica nos índices de criminalidade, mas que se reflete em muros altos que revelam que a população decidiu se voltar à vida privada diante de uma cidade que não transmite a sensação de segurança de um espaço "sacralizado". Esses aspectos revelam que a população reassentada não estabeleceu significativos vínculos afetivos com o novo espaço, não o reconhecendo enquanto lugar.

Assim, é possível perceber que o processo de reassentamento foi fruto de uma visão de desenvolvimento econômico que desconsiderou os fatores humanos envolvidos. Conclui-se, portanto, ressaltando a importância de, nos processos que envolvem um reassentamento obrigatório, se considerar o estudo e a compreensão dos fatores espaciais que estruturam a identidade de um grupo, de modo a minimizar os impactos causados.

\section{REFERÊNCIAS}

BRASIL. Constituição dos Estados Unidos do Brasil (1946). Diário Oficial da União, 15 de out. 1946. Seção 1, p.14119

BRASIL. Decreto-lei $n^{\circ}$ 19.706, de 3 de outubro de 1945. Diário Oficial da União, Poder Executivo, Brasília DF, 9 de out. 1945. Seção 1, p. 15944.

BRASIL. Decreto-lei $n^{\circ}$ 541, de 15 de dezembro de 1948, Coleção de Leis do Brasil, Poder Legislativo, Brasília DF, 17 de dez. 1948. vol. 7, p. 141.

BRASIL. Decreto-lei $n^{\circ}$ 8.031, de 3 de outubro de 1945. Diário Oficial da União, Poder Executivo, Brasília DF, 9 de out. 1945. Seção 1, p. 15929 a 15931.

BRANDI, P. et al (Org.). Companhia Hidro Elétrica do São Francisco (Chesf). Rio de Janeiro: CPDOC, s/d. Disponível em: <http://www.fgv.br/cpdoc/acervo/dicionarios/verbete-tematico/companhia-hidro-eletrica-do-sao-francisco-chesf>. Acesso em: 15/11/2019.

CHESF. CHESF: 70 anos de história. Rio de Janeiro: Centro da Memória da Eletricidade no Brasil, 2018. Disponível em: <http://www.chesf.gov.br/Comunicacao/70anos/index.aspx\#page/6>. Acesso em: 25/11/2019.

COMITÊ DA BACIA HIDROGRÁFICA DO RIO SÃO FRANCISCO. Documentação do Comitê da Bacia Hidrográfica do Rio São Francisco. Disponível em: <https://cbhsaofrancisco.org.br/documentacao/>. Acesso em: 25/09/2019.

COMPANHIA HIDRO ELÉTRICA DO SÃO FRANCISCO (CHESF). Estudo de Alternativa de Sítio para o Novo Núcleo Urbano de Itacuruba. Recife, 1981.

COMPANHIA HIDRO ELÉTRICA DO SÃO FRANCISCO (CHESF). Plano de Implantação do Reservatório de Itaparica. Recife, 1986.

COMPANHIA HIDRO ELÉTRICA DO SÃO FRANCISCO (CHESF). Reassentamento do Reservatório de Itaparica. Recife, 1991.

COMPANHIA HIDRO ELÉTRICA DO SÃO FRANCISCO (CHESF). Usina Hidrelétrica de Itaparica: aspectos ambientais de projetos cofinanciados pelo Branco mundial. [19--]. 
COSTA, S. R. G. (org.). Plano Urbanístico da Nova Cidade de Itacuruba. Recife: SEHAB/CHESF, 1986.

CULLEN, G. Paisagem urbana (1961). São Paulo: Martins Fontes,1983.

DE PROFUNDIS. Direção e Produção: Isabela Cribari. Recife: Set produções Audiovisuais, 2014. 1 DVD.

DIAS, R. F. Panorama do Setor de Energia Elétrica no Brasil. Rio de Janeiro: CMEB, 1988.

ELIADE, M. O sagrado e o profano (1957). Trad. Rogério Fernandes. São Paulo: Martins Fontes 1992.

FIGUEIREDO, M. S. Exílio: Pertencimentos e reconhecimentos em populações deslocadas - o caso Itacuruba. Tese (Doutorado). Programa de Pós-Graduação em Antropologia, UFPE, Recife, 2011.

HALBWACHS, M. (1968). A memória coletiva. Trad. Laurent León Schaffter. São Paulo: Vertice, 1990.

IANNI, O. Estado e Planejamento Econômico no Brasil (1930-1970). Rio de Janeiro, Civilização Brasileira, 1971.

INSTITUTO BRASILEIRO DE GEOGRAFIA E ESTATÍSTICA (IBGE). Histórico da Cidade de Itacuruba. Disponível em: $<$ https://cidades.ibge.gov.br/brasil/pe/itacuruba/historico>. Acesso em: 20/09/2019.

LOPES, L. O Vale do São Francisco. Rio de Janeiro: Ministério de Viação e Obras Públicas, 1955.

LYNCH, K. (1960). A imagem da cidade. Trad. Maria Cristina Tavares Afonso. Lisboa: Edições 70, 1982.

MINISTÉRIO DO MEIO AMBIENTE. Programa de Revitalização da Bacia Hidrográfica do Rio São Francisco (2016). Disponível em: <https://www.mma.gov.br/estruturas/PRSF/ arquivos/diag.pdf>. Acesso em: 08/09/2019.

NORA, P. Entre memória e história: a problemática dos lugares. Projeto História - Revista do Programa de Estudos PósGraduados em História e do Departamento de História da PUC-SP, n. 10. São Paulo, dez.-1993.

OLIVEIRA, N. C. C. A grande aceleração e a construção de barragens hidrelétricas no Brasil. Varia História, v. 34, n. 65, 2018, p. 315-346

PANERAI, P. Análise urbana. Brasília: Editora UnB, 2006.

PENTEADO JR., A. A.; DIAS JR., J. A. Eletrotécnica. In: VARGAS, M. (Ed.). História da técnica e da tecnologia no Brasil. São Paulo: UNESP, 1995.

POLLAK, M. Memória e identidade social. Revista Estudos Históricos, v. 5, n. 10, 1992, p. 200-215.

POLLAK, M. Memória, esquecimento, silêncio. Revista Estudos históricos, v. 2, n. 3, 1989, p. 3-15.

\section{NOTAS}

${ }^{1}$ CREMEPE. Itacuruba afogada na tristeza - 27/05/2007. Dados da Caravana CREMEPE.

2 DIÁRIO DE PERNAMBUCO, Caderno Viver, 15/10/2006. Dados da Caravana CREMEPE.

${ }^{3}$ Apesar de reconhecermos que os habitantes de Itacuruba não compõem propriamente uma sociedade "tradicional", como aquelas as quais Eliade se dedicou no seu clássico texto, entendemos que, como o próprio Eliade adverte, vários traços do homem "primitivo" e das sociedades tradicionais permanecem em setores da sociedade moderna, particularmente naqueles mais isolados, mais dependentes do sítio e vulneráveis economicamente.

${ }^{4}$ Mesmo conscientes que o termo "velho" denota algo em desuso, imprestável, sem uso, o que não era o caso da cidade inundada, resolvemos mantê-lo como designação para a Antiga Itacuruba, pois foi assim que os entrevistados a ela constantemente se referiram, certamente por razões afetivas.

${ }^{5}$ Vargas se embasou no anteprojeto do Ministro da Agricultura Apolônio Sales para a criação de um órgão visando promover o aproveitamento energético da Cachoeira de Paulo Afonso. A construção de uma grande central geradora nessa região seria uma solução definitiva para suas carências no abastecimento energético e uma obra-chave para o desenvolvimento do Nordeste (BRANDI, s/d).

${ }^{6}$ Segundo Oliveira (2018), apesar das grandes expectativas, a ação de interesses privados e a falta de tecnologia/capacitação profissional para lidar com um empreendimento desse porte acabaram barrando a aprovação do PNE e a criação da Eletrobrás, mas os investimentos no desenvolvimento da indústria nacional de materiais e equipamentos para o setor continuaram (PENTEADO JR.; DIAS JR., 1995, p. 257).

${ }^{7}$ O seu curso segue no sentido sul-norte pela Bahia e Pernambuco, quando se altera para leste, desaguando no Oceano Atlântico e marcando a divisa entre Sergipe e Alagoas. Nesse percurso, ele banha 508 municípios e atinge a vida de 20.029 .620 habitantes de acordo com os dados da Codevasf/IBGE, 2018. De acordo com o Ministério do Meio Ambiente (2016), ele representa a maior bacia hidrográfica totalmente brasileira: são $7,5 \%$ do território nacional coberto por suas águas, o que equivale a uma área de 639.219 km², abrangendo sete estados.

${ }^{8}$ A primeira usina hidrelétrica do Nordeste, a Usina de Angiquinho, foi inaugurada em 1913 no vale do Rio São Francisco, para fornecer energia elétrica a uma indústria têxtil de propriedade de Delmiro Gouveia, localizada na cidade de Pedra, hoje Delmiro Gouveia, Alagoas. 
${ }^{9}$ De acordo com a matéria publicada pelo CREMEPE em 2007, $63 \%$ da população apresentava distúrbios mentais e a cidade tinha 25 casos de suicídios a cada 100 mil habitantes por ano, enquanto a média do estado de Pernambuco era de 3 a cada 100 mil habitantes.

NOTA DO EDITOR $\left(^{*}\right)$ : O conteúdo do artigo e as imagens nele publicadas são de responsabilidade do(s) autor(es). 